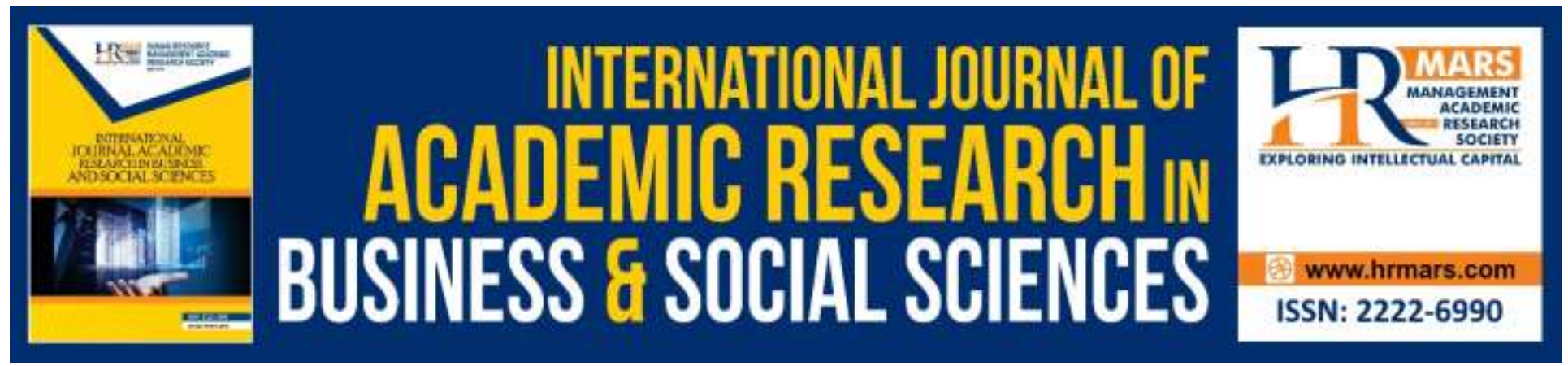

\title{
Conceptual Framework of Maqasid Value in Integrity Issues
}

\author{
M. Fadzhil Mustafa, A. T. Hidayah Abdullah, W. M. Yusof W. Chik, A. Faizol \\ Ismail, Wan Mohd Khairul Firdaus Wan Khairuldin, Noorsafuan Che Noh, \\ Hasnan Kasan
}

To Link this Article: http://dx.doi.org/10.6007/IJARBSS/v9-i11/6594

DOI: 10.6007/IJARBSS/v9-i11/6594

Received: 30 September 2019, Revised: 20 October 2019, Accepted: 01 November 2019

Published Online: 22 November 2019

In-Text Citation: (Mustafa et al, 2019)

To Cite this Article: Mustafa, M. F., Abdullah, A. T. H., Chik, W. M. Y. W., Ismail, A. F., Khairuldin, W. M. K. F. W., Noh, N. C., Kasan, H. (2019). Conceptual Framework of Maqasid Value in Integrity Issues. International Journal of Academic Research in Business and Social Sciences, 9(11), 732-740.

\section{Copyright: (C) 2019 The Author(s)}

Published by Human Resource Management Academic Research Society (www.hrmars.com)

This article is published under the Creative Commons Attribution (CC BY 4.0) license. Anyone may reproduce, distribute, translate and create derivative works of this article (for both commercial and non-commercial purposes), subject to full attribution to the original publication and authors. The full terms of this license may be seen

at: http://creativecommons.org/licences/by/4.0/legalcode

Vol. 9, No. 11, 2019, Pg. 732 - 740

http://hrmars.com/index.php/pages/detail/IJARBSS

JOURNAL HOMEPAGE

Full Terms \& Conditions of access and use can be found at http://hrmars.com/index.php/pages/detail/publication-ethics 


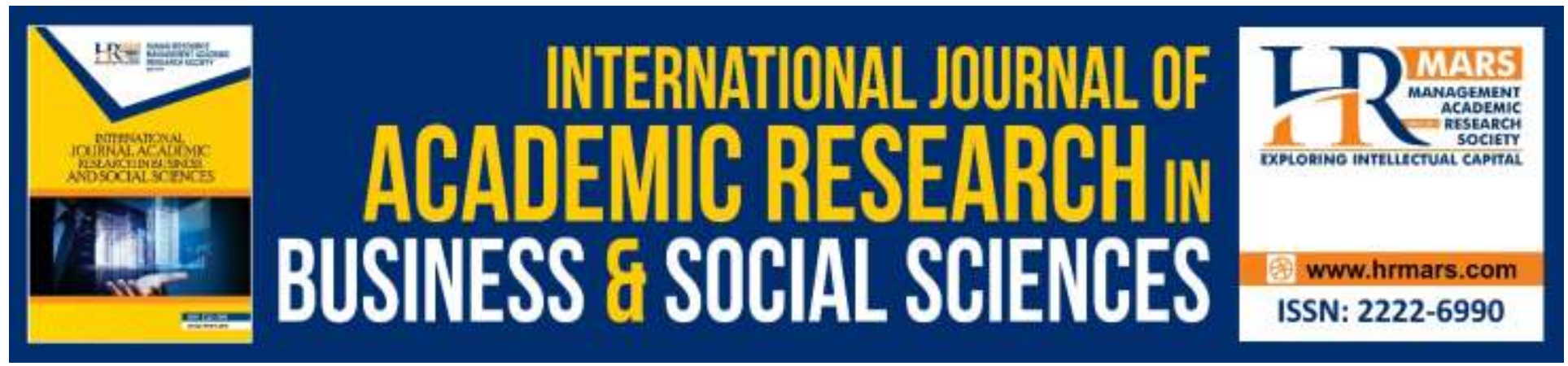

\title{
Conceptual Framework of Maqasid Value in Integrity Issues
}

\author{
M. Fadzhil Mustafa, A. T. Hidayah Abdullah, W. M. Yusof W. \\ Chik, A. Faizol Ismail, Wan Mohd Khairul Firdaus Wan Khairuldin, \\ Noorsafuan Che Noh \\ Faculty of Islamic Contemporary Studies, Universiti Sultan Zainal Abidin
}

\section{Hasnan Kasan}

Citra Centre, Universiti Kebangsaan Malaysia, Malaysia

\begin{abstract}
This paper is aimed at highlighting the concepts and ideas of sharia maqasid values as a highemulated mindset to produce maqasid knowledge in the international arena. In this case, there are many methods of submitting arguments to overcome the current problems of thinking thus resolving several issues, particularly in relation to integrity issues of financial management and political upheaval. In this regard, a study on the sharia maqasid is able to shed light on some important objectives or noble goals behind the implementation of the Islamic taklif through its laws and values. Hence, the idea of maqasid value should be comprehensively understood to shape the administration of property prudently as well as to improve the quality of disseminating of siyasah syar'iyyah from time to time. Based on the qualitative study through library research and analysis of the contents of the book by al-Juwayni, the author strives to explain maqasid knowledge and istidlal method as a cure and treatment of the present conflict. It turns out, it is a collective responsibility to produce a point of understanding among the authoritative parties even though the truth comes from the subordinates. The result, through this prudent approach, must be the value of wisdom and justice for all parties without prejudice.

Keywords: Educational Thought, Islamic Mathematics, KH. Fahmi Basya, Muslim Scholar, Holistic Education.

Introduction

Sharia maqasid (shariah virtue) is an inspiration or the spark of today's minds aimed at enhancing the understanding of community members especially among religious students, Islamic scientists
\end{abstract}


and professionals. It actually carries the aspiration of implied meaning or deep wisdom or the like which is celebrated by the shariah in the laws of the shariah whether in general or specialized in the realization of human wellbeing in this world and in the hereafter (Azhar, 2010).

The definition of sharia means ilzam that is the fulfillment of duties or trust based on the obligation, perfection and pleasure (al-Juwayni, 1997). It has the ability to do the task even though not the choice of a mukallaf. There are several methods that he proposed in the context of Islamic taqwa for the purpose of generating ubudiyya values. Islamic law can be seen from two aspects of maqasid. First; maqasid mukhatib (The Creator of Sharia) and secondly; maqasid mukhatab (mukallaf). Mukallaf is a person who is qualified to rely on the law of sharia for all his deeds. His expertise can be seen and evidenced by several conditions such as survival, intelligence, self-esteem, Islam, know the law of divine law that is defined either through the essential science or with its ability to learn. Hence, the maqasid mukallaf is bound by the deptitat which establishes whether the law is valid or nullified in its deed. Therefore, the maqasid mukallaf must be in line with the sharia maqasid which is outlined (al-Halibi 2009; Khairuldin, 2018).

\section{Maqasid Mukhatib}

a. Taklif Syarak or obligation in Islamic law is aimed at handing out the task that is capable of doing even though it is not the choice of person itself, especially regarding the law of order and the prohibition. While the law of sunnah and makruh are both up to the willingness of person because there is no significance and fines. In this case, al-Juwayni (1997) argues: It means: Indeed, the inspiration of the syarak inspired the assignment of heavy duty from mukhatib even though not through person choice. While circumcision or sunat and makruh are both slightly different as mukhatab is chosen.

b. A comprehensive legal charge or obligation can take place without the actual ability of the mukallaf - a person obligated by law to discharge a legal duty- as the opinion of the al-Ash'ari sect. However, al-Juwayni (1997) asserted that there was a ban from defining something that could not be done or impossible to be done. Which means: Indeed, the establishment of the alAsy'ari sect is a comprehensive discipline that can occur even beyond its ability. But the real intent is to forbid inclination to the impossible. In short, taklif only applies to things that can be done.

c. The order to do something at times does not constitute a ban on doing the opposite of al-Juwayni (1997). Which means: The instruction of doing something is not to be a ban if it does something contrary to it. This is because if there is any ability to follow the contrary, it will not follow the instructions of doing something (at the same time), whereas the act has been the purpose of the instruction and also the claim before it can be done.

d. The act of mukallaf is due to the power of Creator s.w.t. According to al-Juwayni (1997) each mukallaf is required to do something which in fact is part of God's actions. It means: The act of servant (mukallaf) according to al-Ash'ari is valid because of God's power. While the servant is required to do as the will of God's. 
e. Taklif can occur even in contrast to something already known since it is still under the capability of mukallaf (al-Juwayni, 1997; Al Shbail, 2018). Meaning: And it should be charged though different from existing knowledge.

\section{Maqasid Mukhatab}

a. Every taklif given by sharia must be executed by every mukallaf who has the ability (al Juwayni, 1997). Which means: In short; Indeed, only one capable person will be given a taklif.

b. The drunken mukallaf was not charged because he could not understand the instructions. Moreover, he was unable to intend to implement the taklif (al-Juwayni, 1997). Which means: Drunken people cannot be charged. The argument that prevents the taklif is their inability to understand the instructions. Hence, adherence to intention is inadequate.

c. Mukallaf who was forced to do something can be charged because it is included in mukallaf category capable of understanding the command and is able to even perform taklif even in force (al-Juwayni, 1997). Which means: The person being forced can be diverted because he is able to understand and obey the instructions even when in force.

d. Taklif must be implemented even if not rewarded. Contrary to the views of the Mu'tazilians, where they think that it is obligatory to give rewards to each mukallaf. Al-Juwayni (1997) has denied the view firmly: Which means: Mu'tazilian argues that the person being forced to perform the worship should not be charged or tasked by the worship. This is because their policy is to be rewarded for every mukallaf, while the person being forced to do something will not be rewarded. On our side (al-Juwayni), this method is wrong, because the charge or task is still given without any reward. While the method of dealing with rewards and punishment (sin) should be further elaborated in other chapters.

e. Mukallaf kafir is the person who disobeys the order of syarak and must be directed to do syariah branches according to the school of al-Shafi'i. In contrast to the opinion of the followers of Abuhanifa who say they cannot be directed to do so. According to al-Juwayni (1997), the infidels are only commanded to commit to sharia in general and according to his instructions in particular. Which means: Our opinion is that the disbelievers should be commended to be fully committed to the sharia (package) and to follow the guidelines in detail. So whoever disobeys the duty to do so, indeed he has rejected the existing commands.

\section{Istidlal Methods}

According to al-Mu'jam al-Wasit (1990), istidlal in terms of language means claiming a proposition or making something as proof or argument. In terms of terms, al-Juwayni (2003) has explained the concept: It means: Istidlal is a method that hovers between subjugation or argument and vows (research) on the nature of an issue which is examined with the question of a person asking for proof.

Al-Juwayni (1991) also touched on this issue by quoting the contradiction or mistake that occurred among the Moslem scholars in fiqh and the imams (researchers) or spiritual leaders: It means: The respected and famous Moslem scholars and the researchers have disputed opinions 
about istidlal. Whereas, it is a reason that informs the law, which is based on logical reasoning when no agreement or proof is agreed. The justification given is inherent to the law.

In this regard, there are many opinions of Moslem scholars who touched on fiqh issues in every age by introducing the hidden wisdom behind the laws. All these wisdoms are considered as sharia maqasid regarding certain issues or laws. Once the science of figh is studied, written and recorded, there is an important part of the topics of his discussion that touch on sharia maqasid. Now, most of the works related to the proposals of fiqh have taken into account the emphasis on sharia maqasid which is the pillar of law in achieving the goal in line with the requirements of sharia. Actually, it is the priority of al-Juwayni when touching the maqasid in some parts of al-Burhan's work (Ismail, 2007).

Based on the above facts, al-Juwayni (1997) has discussed some of the sharia maqasid methods and his ideas in some of his works, especially in the chapter of al-Qiyas. He succeeded in categorizing the maqasid into three major categories namely daruriyyat, hajiyyat and tahsinat. He also shows some of the maqasid methodjs that can be taken into account. For example, to adopt the general method in istidlal and prioritize it on qiyas jali: Which means: Qiyas jali must be abandoned if it conflicts with general method based on daruriyyat .

For example, qisas punishment is included in human rights. In qisas should be celebrated by equality in qiyas. Based on the qiyas, a group of pilgrims who were involved in a murder case, could not be killed entirely due to killing an individual because no equality. However, they can be punished by death penalty with qisas if convicted of killing the individual, although there is no similarity from the number of those involved based on the kulliyyah and daruriyyat methods (alJuwayni, 1997).

Likewise al-Juwayni (1991) has mentioned some of the maqasid of shariah such as maqasid ibadat, takbirat al-ihram, qisas, hudud, sales, ijarah (rental), and so on. He says: Which means: The content of sharia is a matter of instruction, prohibitions and a must or necessity. The most important thing is worship. Prohibition of sharia has been convicted in the category of destructive matters (great sins) which have restrictions (hudud or qisas). Generally, blood can be maintained with qisas punishment, honor can be maintained with hudud punishment and property can be protected from thieves with punitive punishments.

In this regard, al-Juwayni considers the maqasid to reflect the value of basirah (wisdom) in matters relating to religious affairs. This basirah value has become one of the hallmarks of the popularity of intelectual generation since time immemorial. An example can be observed in the issue of al-ihram during the solat prayer. Al-Juwayni (1991) has quoted al-Shafi'i's words: It means: Al-Shafi'i said when touching the dignity of the nazar or vows (research): Whoever says that there is no purpose for al-Shari' (The prophet s.a.w) in specializing takbir and continuing his duty, nor does it mean for his companions and followers after them amongst the supporters of the Sharia who say that takbir is a specific law - the circumstances of the Muslims at that time were united in spite of the times of change in terms and deeds. However, the khalaf accept the law of the reckoning of the salaf so that if it is assumed that the law is solat with besides takbir then it is considered to be void and must be left- so, whoever says so is no effect on this specialization and it is the matter of wifaqi (current) he has shouted ignorance towards sharia 
maqasid especially in the issue of maqasid mukhatab (mukallaf) according to the perspective of the order and the prohibition of sharia.

Accordingly, al-Juwayni asserted that it should not be totally inferred to the law other than takbir with the law of takbir and also the taslim (giving salam) in the prayer. For example, is the same between the law deliberately applies when prayer and the law of taslim with the reason both can cancel the prayer? The answer of al-Juwayni (1991) can be observed in the following phrase: Which means: And whoever requires in the beauty of the sharia by associating the law deliberately with the law of taslim in the solat prayer, can actually be considered a stubborn hypocrite or a blinded person by Allah s.w.t. We seek guidance from Allah s.w.t and seek His protection from being caught in taklid situation where one follows other people's opinion without knowing its true source.

\section{Pioneers of Maqasid Sharia Ideas}

According to al-Raysuni (1997), al-Juwayni has its own advantages and is a pioneer in the discovery of three famous syariah maqasid ideas namely daruriyyat, hajiyyat and tahsinat. To date, this categorization has become the basic principle of the discussion of maqasid knowledge. al-Juwayni has also led to the discovery of al-daruriyyat al-kubra in the ceremonial taklif. Obviously, there are five general principles that must be carefully maintained. The five general principles include the obligation of preserving religion, soul, intellect, family and wealth (alJuwayni 1997; Ibnashur, 2000). To illustrate the importance of preserving the maqasid sharia, alJuwayni dismissed the al-Ka'bi view that has denied ibahah (option) which is the law of obligatory sharia. In this case, al-Juwayni (1997) firmly disagreed to his views. Which means: Anyone who does not understand the existence of a maqasid sharia in order and prohibition, is actually not in the basirah stage in the formulation of the shari'a. While rejecting ibahah (option) is a great attack on ijmak. Indeed, al-Ka'bi himself and his followers have been preceded by the consent of the people who agreed to ratify the law.

The same is true when al-Juwayni (1997) talks about the idea of reason and proposals in the chapter of al-Qiyas. In this case, he stated: It means: This is what the Muslim scholars say as syariah proposition, while we categorize them into five ideas.

Al-Juwayni has explained in detail the five ideas of maqasid sharia in order of priority. The five ideas are:

a. Daruriyyat-related affairs such as qisas penalties for the purpose of safeguarding and preserving the blood of innocent people and as a restriction not to exceed the limits. In this case, al-Juwayni (1997) said: Meaning: First idea; a law ma'qul al-ma'na. It is (law) al-asl. Ma'qul al-ma'na is aimed at daruriyyat and certified its kulli future goals in accordance with local siyasah. It is the judgment of sharia like the obligation to undergo qisas in its time. The duty is imposed with the preservation of life and restrictions on bloodshed (killing).

b. Matters related to general hajiyyat, but not to the level of daruriyyat such as the need for ijarah affairs (rents) among the public. This category has been mentioned by al-Juwayni (1997) with his words: Meaning: The second idea; a law relating to hajiyyat and not to 
daruriyyat. For example, validation ijarah law. It is based on the general needs of residential houses due to their inability to own it as well as the co-operation of the owner to lend (without payment). Therefore, it is a hajiyyat which is truly outwardly, but it does not reach the degree of daruriyyat as it is in the sale and the like.

c. Non-daruriyyat affairs and not hajiyyat matters that are intended to bring to the mukarramat (tahsinat) such as taharah (purification) and to eliminate impurities and to avoid things that violate the affairs of the living standards. Al-Juwayni (1997) explains it as follows: Meaning: The third idea; a law is unrelated to daruriyyat or hajiyyat, but it differs from it the purpose of bringing the mukarramat or rejecting the opposite matter. Must be included in this category is purifying from the hadath and eliminating impurities. This category can also be expressed by a law that is purely talebih and purportedly through the demand of circumcision such as demands of purification (cleaning, clothing, food, drink and place).

d. Non-daruriyyat affairs and not hajiyyat, but its position is slightly lower than the third notion of dealing with the mandubat matter (circumcision). Its original position is the same as the third category, with the aim of promoting migration, only the demands of the obligation or the necessity to the warehouse is unclear. Hence, it is included in the category of circumcision or sunat which is highly recommended by sharia. This idea is touched by alJuwayni (1997) as follows: It means: The fourth idea: A law that is not based on hajiyyat or daruriyyat, while maqasid achievement is clearly circumvented from the beginning. Previously, in the third notion, his achievement was out of general qiyas. Therefore, it is obviously different from this idea. For example, maqasid kitabah (a pay agreement for mukallaf) is to confirm the independence of the mukallaf and then be circumcised because with the kitabah then there will be independence which deals with different affairs with general qiyas. For example, the master's property belongs to his servant and the conversion of his property to the property of his servant.

e. Totally unclear business of reason and no real claim of maqasid either through daruriyyat, hajiyyat or advocate to tahsinat. This category is less found in the sharia because it is usually the law of the sharia that has certain maqasid and the benefits that each mukallaf can achieve. For example, the claims of the body through the movement of the body are simply not related to maslahah to reject the harm or benefit. The Ta'abbud is like doing the circumcision and the number of rak'ahs in the prayer as well as the determination of the month for fasting and fasting time. This latter idea has been described by al-Juwayni (1997) as follows. Meaning: Fifth Ideas; a law that does not involve its illat at all and no claim daruriyyat, hajiyyat nor the advice to tahsinat. Tasawur of this category is rare, but if it is not capable of rolling its reason in detail, then there is no barrier to imagine it thoroughly. Examples of this category are physical worship solely because it has nothing to do with the purpose of mitigating or benefiting, but it is undeniable that the continuation of the taklif will be able to maintain the health of a mukallaf on the basis of compliance. Likewise, renewing the promise through zikrullah will prevent the act of being abusive and wrongful. This can happen thoroughly. 
Based on the facts above, al-Juwayni is the earliest figure who pioneered the science of sharia maqasid. The proof can be observed through the use of the general maslahah term that related to sharia maqasid (al-Juwayni 1990).

It can also be observed through the opinion of his beloved pupil, al-Ghazali. He (2008) considers that all sharia maqasid whether daruriyyat, hajiyyat or tahsinat are included in the open maslahah. Al-Ghazali (1999) has described the maslahah as jalb al-manfaah (beneficial) and daf' madarrah (rejecting harm). Therefore, he defined the maslahah with al-muhafazah 'ala maqsud al-Shar'ie the preservation of the sharia maqasid. For him, between syariah maqasid is to preserve five things namely religion, soul (spirit), intellect, nasab and wealth. The method is that every business that maintains these five matters is considered maslahah. While every business that attempts to eliminate these five matters is considered mafsadah (harm) and it must be rejected. Hence, rejection of this mafsadah is considered maslahah by his side (al-Ghazali 1999).

Another pupil or follower of al-Juwayni, Ibnabdussalam (2000) argues that the sharia maqasi is merely aimed at bringing maslahah or benefits and rejecting harm. His opinion was recorded in the following words: Which means: And anyone who investigates the sharia maqasid for the purpose of bringing maslahah and rejecting the damages, must have a clear conviction or knowledge that should not neglect the maslahah or approach the mafsadah. Although there is no script, ijmak and qiyas, but understanding the essence of syarak will lead to the understanding.

\section{Conclusions}

The discussion regarding the sharia maqasid in the implementation of the sharia proved that alJuwayni was a pioneer in triggering the idea of daruriyyat, hajiyyat and tahsinat and other value ideas. Interestingly, he was able to produce intellectuals such as al-Ghazali, al-Izz bin Abd alSalam, al-Razi, al-Shatibi and many more who step further to widen the scope of a significant or fiqh method.

In addition, al-Juwayni successfully introduced the istidlal method when expressing the argument with his own style and culture of thought. This is because this method is capable of encouraging the mujtahid to be more widespread when compared to the use of maslahah mursalah. Therefore, he himself incorporates the istishab method into this istidlal method.

As a result, maqasid in financial management is to be achieved by focusing on fulfillment, safeguarding property and property rights, setting aside harm, stumbling over ignorance and fraud, preventing greed from consuming fraudulent property, opening investment doors and widening trade within society and etc. This is the proper value to govern the management of state property and political governance. 
INTERNATIONAL JOURNAL OF ACADEMIC RESEARCH IN BUSINESS AND SOCIAL SCIENCES

Vol. 9, No. 11, November, 2019, E-ISSN: 2222-6990 ㄷ 2019 HRMARS

\section{Acknowledgments}

We express our deepest gratitude to Malaysian Ministry of Education and Centre for Research Management, Innovation \& Commercialization (RIMC), UniSZA, Malaysia for supporting this publication.

\section{Corresponding Author}

Rahimah Embong, Ph.D, is Associate Professor at Department of Education, Dakwah \& Islamic Civilization, Faculty of Islamic Contemporary Studies, Universiti Sultan Zainal Abidin (UniSZA), Kampus Gong Badak, 21300 Kuala Nerus. Terengganu, Malaysia.

Email: rahimahembong@unisza.edu.my

\section{References}

Al-Qur'an al-Karim

Al-Baqi, M. F. A. (1987). Al-Mu'jam al-Mufarris li Alfaz al-Qur'an al-Karim. Kaherah: Dar al-Hadith. Al-Bustani, F. I. (1956). Munjid al-Tullab. Beirut: Matbaah al-Kathulikiyyah.

Al-Buti, M. S. R. (1986). Dawabit al-Maslahah fi al-Shariah al-Islamiyyah. Beirut: Muassasat alRisalah.

Al-Durayni, M. F. (1997). al-Manahij al-Usuliyyah fi al-ljtihad bi al-Ra'y fi al-Tashri' al-Islami. Beirut: Muassasat al-Risalah.

Al-Ghazali, M. M. (1999). Tahq. Zakaria Umayrat. Shifa' al-Ghalil fi Bayan al-Shabah wa alMukhayyal wa masalik al-Ta'lil. Beirut: Dar al-Kutub al-Ilmiyyah.

Al-Juwayni, A. M. (1990). Ghiyath al-Umam fi Iltiyath al-Zulam. Iskandariyyah: Dar al-Da'wah.

Al-Juwayni, A. M. (1991). Al-Burhan fi Usul al-Fiqh. Mansurah: Dar al-Wafa'.

Al-Juwayni, A. M. (1997). Al-Burhan fi Usul al-Fiqh. Beirut: Dar al-Kutub al-Ilmiyyah.

Al-Shatibi, A. I. (1991). Al-Muwafaqat fi Usul al-Shariah. Beirut: Dar al-Kutub al-Ilmiyyah.

Al Shbail, M. O. (2018). The Effect of Role Ambiguity and Role Conflict on Dysfunctional Audit Behaviour: Evidence from Jordan, International Journal of Academic Research in Accounting, Finance and Management Sciences 8 (3): 17-25.

Azhar, H. S. (2010). Maqasid al-Shariah 'Inda Imam al-Haramayn wa Atharuha fi al-Tasarrufat alMaliyyah. Riyadh: Maktabah al-Rushd.

Bayyah, A. (2006). 'Alaqah Maqasid al-Shariah bi Usul Fiqh. London: Muassasat al-Furqan.

IbnAbdussalam. (2000). Qawa'id al-Ahkam min Masalih al-Anam. Beirut: Dar al-Kutub alIlmiyyah.

Jabatan Kemajuan Islam Malaysia. (1999). Tafsir Pimpinan al-Rahman kepada Pengertian alQur'an. Kuala Lumpur: Darulfikir.

Khairuldin, W. M. K. F. W. (2018). Fatwa Role in Education and Legal Dispute in Malaysia. International Journal of Academic Research in Progressive Education and Development, 7(4), 295-302. 